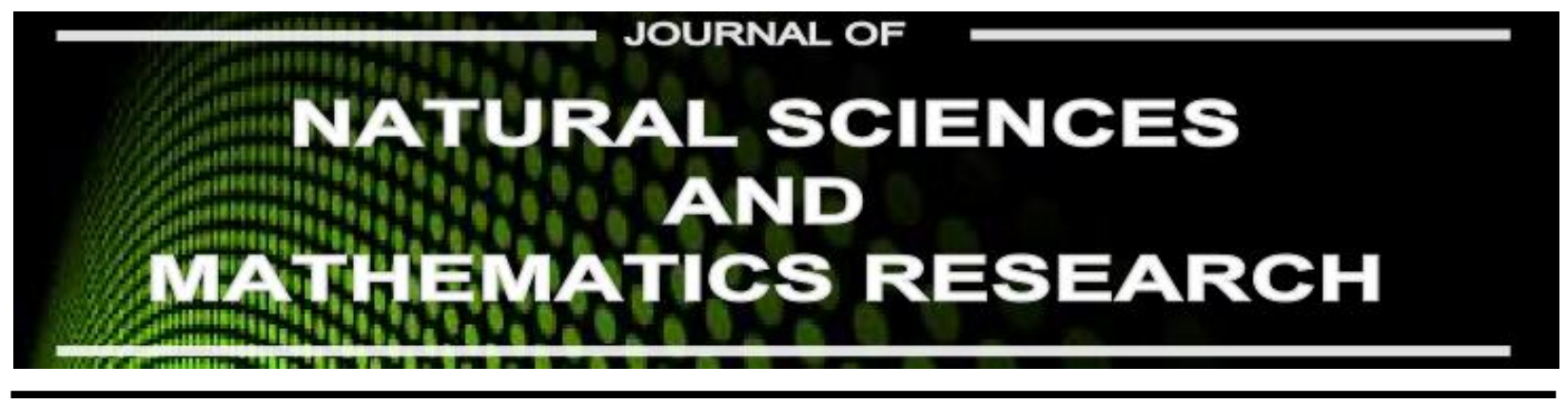

Available online at http://journal.walisongo.ac.id/index.php/jnsmr

\title{
The Abundance Analysis of Mangrove Crab (Scylla spp.) in the Mangrove Area at Senik Hamlet, Bedono Village, Sayung Subdistrict, Demak District
}

Miftahul Adha1, Siti Mukhlishoh Setyawati' ${ }^{1}$ and Dian Triastari Armanda'

${ }^{1}$ Department of Biology, Faculty of Science and Technology, Universitas Islam Negeri Walisongo, Semarang, Central Java, Indonesia

Corresponding author: siti.mukhlishoh@walisong o.ac.id

Recived: 20 April 2016, Revised: 20 May 2016, Accepted: 25 June 2016.

\begin{abstract}
s
The abration at Senik hamlet, Bedono village, Demak district has alternated the land became mangrove ecosystem's area. This ecosystem supply the habitat such as group of mangrove crab (Scylla $s p$ ). The purpose of this research to analyze the abundance of mangrove crab at various location in the mangrove's ecosystem at Senik's hamlet. The mangrove crabs sampling are taken at three station in the Rejosari The result of variances analyzis prove there are the significant differences ( $\left.F_{\text {hitung }}=17,67 ; \alpha=0,05\right)$ in the abundance of mangrove crab among station. The most abundant of mangrove crab in the station III (815 ind/Ha), then Station II (563 ind/Ha), and Station I (341 ind/Ha), The Domination of mangrove crab in the three of station is Scylla tanquebarica species (female and the age is adolescent). The analyzis result of Pearson Products Moment at the environment parameter obtained that the water salinity $(r=0,77)$ and the depth of water $(r=0,72)$ to be the most powerfull positive correlation with the abundance of mangrove crab. The conclusion of this research is the height of the abundance of mangrove crab at Senik's Hamlet supported by the combination of various environment factor, especially the salinity factor, the water depth, and the density of mangrove vegetation. (C2016 JNSMR UIN Walisongo. All rights reserved
\end{abstract}

Key words: The abundance; Mangrove crab; Scylla spp., Mangrove.

\section{Introduction}

One of the many animals captured and exploited from the mangrove ecosystem area for the substance of consuming is mangrove crab (Scylla spp. Mangrove crab is an invertebrate (not spine) animal from the Crestacea class Arthropoda phylum that has a coastal habitat on the mud base, especially in the mangrove ecosystem. The resources of Mangrove ecosystem that stretch across the archipelago, produced Indonesia well known 
as a large crab exporter compared to other crab-producing countries. This respectable of mangrove crab comodity is advantaged as the economy increase for around society of the coastal area beach [1].

The drowning of some settlements in Senik Hamlet, Bedono village, has changed the geographical condition [2]. The alteration in geographical conditions caused alteration in the mangrove ecosystem in Bedono Village, such as coastal biota. One of these biota is a mangrove crab that depends most of its life on the mangrove ecosystem. The alteration that occurred in mangrove crabs also has consequence in the result of coastal catches. Based on the initial hypothesis, it is necessary to do a research to determine the condition of mangrove crabs in the mangrove ecosystem at Bedono Village, Demak.

The purpose of this research to analyze the abundance of mangrove crab at various location in the mangrove's acosystem at Senik's hamlet.

\section{Experiments Procedure}

This type of research is quantitative field research. Quantitative research is used to determine the level of influence, the correlation or association between variables, or the level of a variable by the technique of measurement [3]. The data quantitatively processed in this study are primary data (data abundance of mangrove crab) and supporting data (environmental parameters).

The variables compared in this research are the crab abundance at a station with other stations and variables correlated in this research is the abundance of mangrove crab with environmental parameters. The specific sampling location at the Rejosari River that get through the mangrove ecosystem of Dukuh Senik.

The determination of the sampling location focused on this river is also based on the catchment area of the fisherman. The catchment area of fishermen is an area of catching mangrove crabs and other animals such as shrimp and fish. Another reason the selection of sampling sites is due to the activity
/ habit of living the mangrove crab. Mangrove ecosystem is a habitat of mangrove crab, while the river flow is the distribution of mangrove crab in mangrove ecosystem.

The duration of this study is for 22 days, from March 14, 2015 to April 4, 2015. The timing is due in the months of rainfall, tidal, and sea waves have a high enough frequency, so that mangrove crabs tend to settle and take refuge in the ecosystem Mangroves. In addition, it is expected that in those months the female crabs have returned to the mangrove ecosystem after undergoing the spawning season estimated between December-January.

\section{Determination of Research Station}

The next step is set 3 stations of observation that is on the flow of the Rejosari River located in the mangrove ecosystem Dukuh Senik. Description and drawing of observation stations at the watershed as shown as Figure 1.

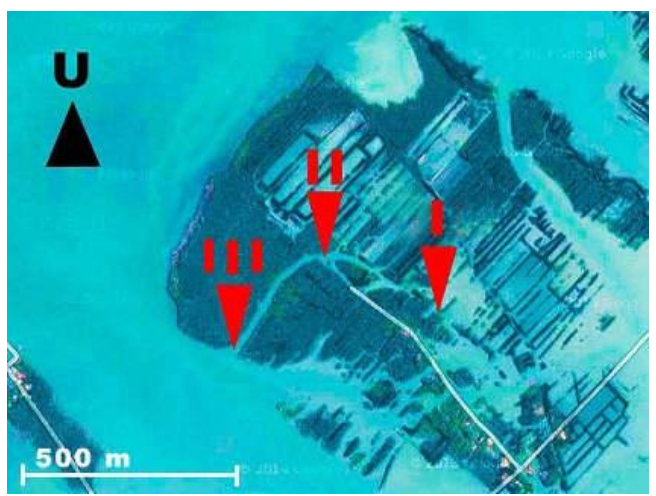

Figure 1. The Location of determination station [4]

- Station I : The first station is at the start of the river stream entering the mangrove ecosystem.

- Station II : The second station is at the second of the river stream entering the mangrove ecosystem.

- Station III : The third station located at mangrove ecosystem in the estuary of river.

\section{Sampling of main data}

The main data sampling technique (mangrove crab) using Purposive Random 
Sampling (non-probability method). This method is a technique of taking sample data with a certain balance, so that each sample data can represent the population. While the determination of the sampling point is randomly performed [5].

Sampling data taken 1 times a week and repeated 3 times. The reason for taking mangrove crab data by giving time lag to avoid the void of the sample area. If sampling is performed consecutively it is feared during the second and third repetitions there will be no mangrove crabs in the study area.

\section{Result and Discussion}

\section{Abundance Analysis of Mangrove Crab}

The sampling of mangrove crab applied plots with the size of each plot $5 \mathrm{~m} \times 5 \mathrm{~m}$ or with an area of $25 \mathrm{~m}^{2}$. The calculations with the formula of abundance and unit conversion of the area performed yield the data as shown as in Table 1.

Table 1. The Data of the mangrove crab abundance each station

\begin{tabular}{ccc}
\hline NO & Station & $\begin{array}{c}\text { The Abundance } \\
\text { (ind/Ha) }\end{array}$ \\
\hline 1 & I & 341 \\
\hline 2 & II & 563 \\
\hline 3 & III & 815 \\
\hline & Average & 573 \\
\hline
\end{tabular}

Station III is the location that has the most abundant which is 815 ind / Ha. There are several for the cause of higher abundance. One of them is the location of the station located at the mouth of the river. The river estuary is the outlet of the mangrove crab. Organic matter carried by river currents also settles on the estuary of this river, thus providing food for the mangrove crab.

Station II has lower abundances than Station III, which is 563 ind / Ha. This is because the condition of the location that is farther from the estuary of the river (compared with Station III), so the activity of mangrove crab is not as high as the estuary river.
The lowest abundance is found out at Station I (341 ind/Ha). One of the reason factor is the number of mangrove vegetation. Mangrove vegetation that causes little organic matter (mangrove remnants) is also slightly in number. More organic matter carried by the flow of water and empties around Station III.

Another factor causing mangrove crabs is less like Station I is the low water depth of this location, which is about $42 \mathrm{~cm}-50 \mathrm{~cm}$. When the water recedes, the depth becomes lower (reduced to $15 \mathrm{~cm}$ ) which can inhibit the movement of mangrove crab, so that mangrove crabs avoid Station I.

The abundance analysis of mangrove crab between stations performed by ANOVA method. It aims to strengthen evidence of whether or not there are differences in abundance of each station. [6]. Based on the anova test, the abundance of mangrove crabs between stations proved to be significantly different.

$$
\begin{aligned}
\text { Hasil }= & F_{\text {hitung }}>F_{\text {tabel }} \\
& 17,678>3,40 ; \alpha 0,05
\end{aligned}
$$

\section{Analysis of Abundance Relationship of Mangrove Crabs with Environmental Parameters}

The analysis used to determine the relationship between abundance of mangrove crab with environmental parameters is pearson product moment analysis and multiple correlation.

$$
\begin{aligned}
& \mathrm{X}_{\mathrm{i}}=\text { Variable environmental parameters } \\
& \mathrm{X}_{1}=\text { Water temperature variable } \\
& \mathrm{X}_{2}=\text { Water } \mathrm{pH} \text { variable } \\
& \mathrm{X}_{3}=\text { Water salinity variables } \\
& \mathrm{X}_{4}=\text { Water depth variable } \\
& \mathrm{X}_{5}=\text { Water brightness variables } \\
& \mathrm{Y}=\text { Variable abundance of mangrove crab }
\end{aligned}
$$

The results obtained using SPSS 16 applications can show in Table 2. The analysis data (Table 2) show that there are 2 environmental parameters that have significant influence when correlated with abundance of mangrove crab, that is, water salinity and water depth, while environmental parameters of water $\mathrm{pH}$, water temperature and water brightness do not show significant 
effect to abundance of mangrove crab. This is possible because the data of these three parameters have the same average value in each station during sampling.

Table 2. Data Correlation Analysis Pearson Product Moment One Variable Parameter Environment With Mangrove Crab Variables

\begin{tabular}{cccccc}
\hline $\begin{array}{c}\text { Varia } \\
\text { ble }\end{array}$ & X1.Y & X2.Y & $X 3 . Y$ & $X 4 . Y$ & $X 5 . Y$ \\
\hline $\begin{array}{c}\text { The } \\
\text { Value }\end{array}$ & $-0,027$ & 0,137 & 0,777 & 0,721 & $-0,015$ \\
$r_{\text {hitung }}$ & & & & & \\
& & & & & \\
\hline
\end{tabular}

${ }^{*} r_{\text {tabel }}=0,396(\alpha=0,05)$

Salinity has a significant effect on the abundance of mangrove crabs. This is because the salinity value obtained at each observation station has a noticeable difference. The occurrence of this difference is influenced by the movement of water that occurs in the observation station. There are two movements of water that affect its salinity, the waves of sea water and the river.

Waves of sea water cause high salinity water from the ocean mixed with water in the mangrove ecosystem. Station III closest to the open sea has the highest impact of water mixing, so the salinity becomes higher than other observation stations. Station I has the lowest salinity compared to other observation stations. The location of Station I is the furthest from the open sea, thus less affected by the high-salinity water of the open ocean. The low water salinity of Station I is also caused by mixing with the freshwater stream (low salinity) [7].

Mangrove crabs are known to grow well in salinity between 15 ppt - 35 ppt. However, salinity higher than $20 \mathrm{ppt}$ is preferred to mangrove crab [8]. Station III which has a range of 20 ppt salinity and Station I has a lower salinity range of 18 ppt range. Mangrove crabs more commonly found in Station III are possible because Station III has a higher salinity which is preferable to mangrove crabs.

Water depth is a parameter that also has significant value to the abundance of mangrove crab. The data obtained at Station III at the mouth of the river has a higher depth than Station I which is closer to the upstream. Station III has a depth in the range of $70 \mathrm{~cm}$, while Station I has a depth with a range of $45 \mathrm{~cm}$.

Station III located at the mouth of the river has waters that never run out of water, when the sea water receded, so that more mangrove crab found in this location. Station I does not run out of water during low tide (water depth at low tide is $15 \mathrm{~cm}$ ). However, this depth is less favored for mangrove crabs because it reduces its ability to move, resulting in less mangrove crab found on Station I.

Table 3 shows that there are 7 simultaneous relationships of 10 possibilities analyzed. The results of the analysis of 7 data indicate that there is a significant relationship, while the results of the other 3 data analysis do not show any significant relationship.

Water salinity and water depth variables have a significant correlation to abundance of mangrove crabs in the previous pearson product moment correlation analysis. However, the other 3 variables (water $\mathrm{pH}$, water temperature and brightness) did not have a significant correlation to abundance of mangrove crabs.

Table 3. Data Relation Two Variable Parameter Environment with Mangrove Crab Variables

\begin{tabular}{clc}
\hline No & $\begin{array}{c}\text { Enviroment Parameter } \\
\text { Variables }\end{array}$ & $\begin{array}{c}\text { Mangrove Crab } \\
\text { variables }\end{array}$ \\
\hline 1 & Temperature pH & - \\
\hline 2 & Temperature and Salinity & $\mathrm{V}$ \\
\hline 3 & Tempereture and depth & $\mathrm{V}$ \\
\hline 4 & $\begin{array}{l}\text { Tempereture and } \\
\text { Brghtness }\end{array}$ & - \\
\hline 5 & $\mathrm{pH}$ and Salinity & $\mathrm{V}$ \\
\hline 6 & pH and Depth & $\mathrm{V}$ \\
\hline 7 & pH and Brightness & - \\
\hline 8 & Salinity and Depth & $\mathrm{V}$ \\
\hline 9 & Salinity and Brigtness & $\mathrm{V}$ \\
\hline 10 & Depth and Brightness & $\mathrm{V}$ \\
\hline$*$ V = contained relationships, & \\
\multicolumn{2}{c}{$-=$ no contained relationships } &
\end{tabular}


The three variables of environmental parameters ie water $\mathrm{pH}$, water temperature and brightness, previously (on Pearson product moment correlation analysis) did not have significant relationship with abundance of mangrove crab, it turned out to be correlated significantly after multiple correlation analysis. The environmental parameters variables that become related after multiple correlation analysis are all environmental parameter variables that correlate with water salinity variables and water depth variables, as shown as Table 4 . Temperature-pH, brightness-temperature and $\mathrm{pH}$-brightness are 3 multiple correlation data that have no significant relationship with abundance of mangrove crab, while salinitytemperature, pH-salinity, salinity-brightness, depth-temperature, pH-depth and depthbrightness are 7 data of double correlation which have significant relation with abundance of mangrove crab

All the environmental parameter variables that correlate together with the salinity and water depth variables are related to the abundance variables of mangrove crab. This is because the salinity and water depths have a significant relationship with the abundance of mangrove crabs, so other parameters that are correlated with these two parameters have a significant relationship.

Analysis of the Mangrove Vegetation Relation with Abundance of Mangrove Crabs

The condition of mangrove vegetation in the three stations under research has different conditions. Station I is a research location that has the lowest density of mangrove vegetation. This low mangrove vegetation density conditions is directly proportional to the abundance of mangrove crab. Mangrove crabs at Station I have the least abundance compared to other research stations. Station III has the most dense mangrove vegetation. The amount of abundance of mangrove crabs is also the most abundant compared to other locations, so it can be concluded that the mangrove vegetation density conditions are directly proportional to the abundance of mangrove crabs in this research.
Table 4. The Influence of Multiple Correlations Between 2 Variable Parameters Environment With Abundance of Mangrove Crabs

\begin{tabular}{|c|c|c|c|}
\hline No & Variable 1 & Variable 2 & $\begin{array}{c}\text { Significance } \\
\text { relationsh with } \\
\text { mangrove Crabs } \\
\text { Abundance }\end{array}$ \\
\hline \multirow[t]{4}{*}{1} & \multirow[t]{4}{*}{ Salinity } & Temperature & $\begin{array}{l}\text { Significant } \\
\text { Relationship }\end{array}$ \\
\hline & & $\mathrm{pH}$ & $\begin{array}{l}\text { Significant } \\
\text { Relationship }\end{array}$ \\
\hline & & Depth & $\begin{array}{l}\text { Significant } \\
\text { Relationship }\end{array}$ \\
\hline & & Brightness & $\begin{array}{l}\text { Significant } \\
\text { Relationship }\end{array}$ \\
\hline \multirow[t]{3}{*}{2} & \multirow[t]{3}{*}{ Depth } & Temperature & $\begin{array}{l}\text { Significant } \\
\text { Relationship }\end{array}$ \\
\hline & & $\mathrm{pH}$ & $\begin{array}{l}\text { Significant } \\
\text { Relationship }\end{array}$ \\
\hline & & Brightness & $\begin{array}{l}\text { Significant } \\
\text { Relationship }\end{array}$ \\
\hline \multirow[t]{2}{*}{3} & \multirow[t]{2}{*}{ Temperature } & $\mathrm{pH}$ & $\begin{array}{l}\text { No Significant } \\
\text { Relationship }\end{array}$ \\
\hline & & Brightness & $\begin{array}{l}\text { No Significant } \\
\text { Relationship }\end{array}$ \\
\hline 4 & $\mathrm{pH}$ & Brighness & $\begin{array}{l}\text { No Significant } \\
\text { Relationship }\end{array}$ \\
\hline
\end{tabular}

Mangrove crab is a biotic component that also has a reciprocal relationship to mangrove vegetation and environmental parameters, so the relationship is no longer a one-way. The mutual relationship between mangrove crabs, mangrove vegetation and environmental parameters can be observed in food webs in the mangrove ecosystem

Vegetation of mangrove is the main link in food webs in mangrove ecosystem. Serasah mangrove used mud crab as food. The remaining mangrove crabs decomposed by microorganisms into nutrients. Nutrient beneficial returns to mangrove vegetation [9]. The availability of nutrients has an effect on the fertility of mangrove vegetation. Sufficient nutrients will make mangrove vegetation more fertile [10].

The fertility of mangrove vegetation has an impact on some environmental parameters conditions such as oxygen levels. The rich mangrove vegetation produces abundant oxygen. Mangrove crabs and other acoustic organisms use oxygen produced by mangrove vegetation. The availability of oxygen has less impact on the decreased physiology of 
mangrove crabs and other mangrove organisms. Mangrove crabs and other mangrove organisms also provide benefits to mangrove vegetation, which helps the photosynthesis of mangrove vegetation [10].

The above analysis is one of the complex picture of mangrove ecosystem condition which has the chance to become the determinant factor of abundance of mangrove crab. The complex determinant factor of abundance of mangrove crab in this mangrove ecosystem become limitation in this research, so abundance of mangrove crab can not be studied more broadly. Further research is needed to analyze the abundance of mangrove crabs in more detail.

\section{Conclusion}

The dominance of mangrove crabs on the three observation stations is Scylla tanquebarica species, female gender and teen crab age. The analysis result of environmental parameters variable with abundance variable of mangrove crab using Pearson Products Moment analysis indicated that water salinity parameter $(\mathrm{r}=0.77)$ and water depth parameter $(r=0.72)$ were two parameters that had the strongest positive correlation to the abundance of mangrove crab. The analysis result of environmental parameters variable with abundance variable of mangrove crab using multiple correlation analysis. The density of mangrove vegetation also supports the high abundance of mangrove crabs. The closer the mangrove vegetation, the higher the abundance of mangrove crabs.

\section{Acknowledgment}

The author wish to thank Department of Biology, Universitas Islam Negeri Walisongo Semarang for financial support in this research.

\section{References}

[1] I. Kanna, Budidaya Kepiting Bakau. Yogyakarta: Kanisius, 2002.

[2] A. R. Zaky, "Kajian Kondisi Lahan Mangrove di Desa Bedono, Kecamatan Sayung, Kabupaten Demak dan Kelurahan Mangunharjo, Kecamatan Tugu, Kota Semarang," J. Mar. Res., 2012.

[3] Sugiyono, Metode Penelitian Pendidikan. Bandung: Alfabeta, 2012.

[4] Google, "Peta Desa Begono," 2014. [Online]. Available: http://www.map.google.com/Bedono/. [Accessed: 01-Jan-2014].

[5] A. P. Erwan, Metode Penelitian Kuantitatif. Yogyakarta: Gava Media, 2007.

[6] Riduwan and Sunarto, Pengantar Statistika untuk Penelitian Pendidikan, Sosial, Ekonomi, Komunikasi, dan Bisnis. Bandung: Alfabeta, 2013.

[7] A. Nontji, Laut Nusantara. Jakarta: Djambatan, 1993.

[8] A. Soim, Pembesaran Kepiting. Bandung: Penebar Swadaya, 1995.

[9] C. Saparintio, Pendayagunaan Ekosistem Mangrove. Semarang: Dahara Prize, 2007.

[10] M. K, Melestarikan Sumber daya Air dengan Teknologi Rawa Buatan. Yogyakarta: Gadjah Mada University Press, 2003. 